\title{
Electrochemical Behaviour of Iron in Simulated Acid Rain in Presence of Achillea Millefolium L.
}

\author{
Zora Pilić, Ivana Martinović and Gloria Zlatić \\ Department of Chemistry, Faculty of Science and Education, University of Mostar, Mostar, Bosnia and \\ Herzegovina \\ *E-mail: zora.pilic1@gmail.com
}

doi: $10.20964 / 2018.06 .29$

Received: 10 February 2017 / Accepted: 24 March 2018 / Published: 10 May 2018

\begin{abstract}
The effect of the aqueous extract of Achillea millefolium L. (AM) on the electrochemical behaviour of iron in a simulated acid rain solution ( $\mathrm{pH}$ 4.5) was studied by electrochemical techniques cyclic voltammetry, potentiodynamic polarization and electrochemical impedance spectroscopy. Experiments were carried out over a wide range of AM concentrations. The results of all techniques showed that AM extract contributes to iron passivation. The films formed in the presence of AM extract were thinner and more resistive then the films formed in pure simulated acid rain solution. The AM extract adsorbed on the iron according to the Freundlich isotherm. The thermodynamic data indicated physical adsorption of the AM extracts on the iron surface. The concentration of the metallic ions released into solution, measured by atomic absorption spectroscopy, was in accordance with the results obtained from the electrochemical techniques.
\end{abstract}

Keywords: Iron; Achillea millefolium L. extract; Simulated acid rain; Electrochemical methods; Atomic absorption spectrometry

\section{$\underline{\text { FULL TEXT }}$}

(C) 2018 The Authors. Published by ESG (www.electrochemsci.org). This article is an open access article distributed under the terms and conditions of the Creative Commons Attribution license (http://creativecommons.org/licenses/by/4.0/). 